


\section{PROCUREMENT REVIEW}

GUIDANCE NOTE ON PROCUREMENT JUNE 2018 


\section{(c) $(9)$ Creative Commons Attribution-NonCommercial-NoDerivs 3.0 BY NC ND IGO license (CC BY-NC-ND 3.0 IGO)}

(C) 2018 Asian Development Bank

6 ADB Avenue, Mandaluyong City, 1550 Metro Manila, Philippines

Tel +632632 4444; Fax +6326362444

www.adb.org

Some rights reserved. Published in 2018.

ISBN 978-92-9261-220-7 (print), 978-92-9261-221-4 (electronic)

Publication Stock No. TIM189414-2

DOI: http://dx.doi.org/10.22617/TIM189414-2

The views expressed in this publication are those of the authors and do not necessarily reflect the views and policies of the Asian Development Bank (ADB) or its Board of Governors or the governments they represent.

ADB does not guarantee the accuracy of the data included in this publication and accepts no responsibility for any consequence of their use. The mention of specific companies or products of manufacturers does not imply that they are endorsed or recommended by ADB in preference to others of a similar nature that are not mentioned.

By making any designation of or reference to a particular territory or geographic area, or by using the term "country" in this document, ADB does not intend to make any judgments as to the legal or other status of any territory or area.

This work is available under the Creative Commons Attribution-NonCommercial-NoDerivs 3.0 IGO license (CC BY-NC-ND 3.0 IGO) http://creativecommons.org/licenses/by-nc-nd/3.o/igo/. By using the content of this publication, you agree to be bound by the terms of this license. For attribution and permissions, please read the provisions and terms of use at https://www.adb.org/terms-use\#openaccess.

This CC license does not apply to non-ADB copyright materials in this publication. If the material is attributed to another source, please contact the copyright owner or publisher of that source for permission to reproduce it. ADB cannot be held liable for any claims that arise as a result of your use of the material.

Please contact pubsmarketing@adb.org if you have questions or comments with respect to content, or if you wish to obtain copyright permission for your intended use that does not fall within these terms, or for permission to use the ADB logo.

Notes:

In this publication, “\$” refers to United States dollars.

Corrigenda to ADB publications may be found at http://www.adb.org/publications/corrigenda. 
Table, Figures, and Box

About This Publication

$\mathbf{v}$

Abbreviations

viii

Executive Summary

ix

$\begin{array}{ll}\text { I. Introduction } & 1\end{array}$

II. Prior Review 3

III. Post Review (Sampling) 6

IV. Contract Review and Sampling Methodology 8

Appendix: Templates for Post Review (Sampling) 13 


\section{TABLE, FIGURES, AND BOX}

\section{TABLE}

Risk Rating Descriptions for ADB's Post Review (Sampling) Report

\section{FIGURES}

1. The ADB Procurement Cycle 2

2. Indicative Sample Size for Post Review 9

BOX

Variables to Consider When Creating Groups of Similar Contracts for Post Review (Sampling) 


\section{ABOUT THIS PUBLICATION}

In April 2017, the Asian Development Bank (ADB) approved its new procurement framework, the ADB Procurement Policy: Goods, Works, Nonconsulting and Consulting Services (2017, as amended from time to time); and the Procurement Regulations for ADB Borrowers: Goods, Works, Nonconsulting and Consulting Services (2017, as amended from time to time). These replace the former Guidelines on the Use of Consultants (2013, as amended from time to time) and Procurement Guidelines (2015, as amended from time to time). The procurement policy and the procurement regulations address the procurement activities of project executing agencies and implementing agencies on projects financed in whole or in part by a loan or grant from ADB, or by ADB-administered funds. ADB designed the 2017 procurement policy to deliver significant benefits and flexibility throughout the project procurement cycle, as well as to improve project delivery through a renewed focus on the concepts of quality, value for money (VFM), and fitness for purpose.

This note is part of a series of guidance notes published by ADB in 2018 to accompany the 2017 procurement policy and the procurement regulations. Each note discusses a topical issue for borrowers (including grant recipients), bidders, and civil society under the new framework (see list below). The guidance notes cross-reference each other frequently and should be read in conjunction. All references to "guidance notes" pertain to these notes. The notes may be updated, replaced, or withdrawn from time to time.

\section{List of Guidance Notes for the 2017 ADB Procurement} Policy and the Procurement Regulations

1. Value for Money

2. Procurement Risk Framework

3. Strategic Procurement Planning

4. Procurement Review

5. Alternative Procurement Arrangements

6. Open Competitive Bidding

7. Price Adjustment

8. Abnormally Low Bids

9. Domestic Preference

10. Prequalification

11. Subcontracting

12. Consulting Services Administered by ADB Borrowers

13. Nonconsulting Services Administered by ADB Borrowers
14. High-Level Technology

15. Quality

16. Bidding-Related Complaints

17. Noncompliance in Procurement

18. Standstill Period

19. State-Owned Enterprises

20. E-Procurement

21. Framework Agreements for Consulting Services

22. Public-Private Partnerships

23. Contract Management

24. Fragile, Conflict-Affected, and Emergency Situations 
ADB procurement reforms intend to ensure VFM by improving flexibility, quality, and efficiency throughout the procurement cycle (see illustration below and the Guidance Note on Value for Money). VFM is part of a holistic procurement structure with three support pillars: efficiency, quality, and flexibility. The two key principles of transparency and fairness weave across all elements of the structure.

\section{Transparency}

\section{Value for Money}

The effective, efficient, and economic use of resources, which requires an evaluation of relevant costs and benefits along with an assessment of risks, nonprice attributes, and/or total cost of ownership as appropriate

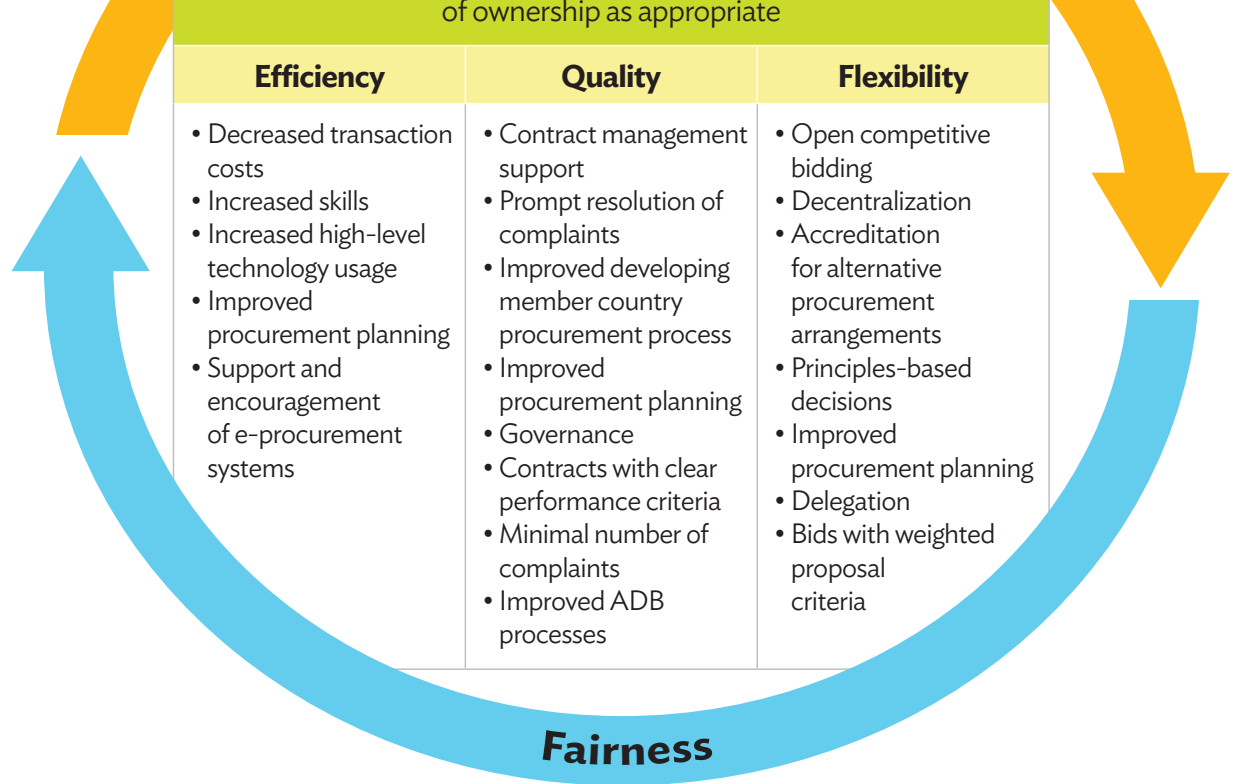

\section{(1) Time}

Time is an important element of VFM. When a project is delivered promptly or when a process is completed rapidly, greater value is created for all stakeholders. For example, a road project completed early provides economic benefit, security, or other value to the community it serves. It increases the return on investment to the executing agency and accelerates the project and payment cycle to the successful bidder. Likewise, a project delivered late loses significant value.

When considering VFM in the context of procurement, pay attention to anything that (i) shortens the procurement cycle time frame or (ii) accelerates delivery of the development project. 


\section{$\Omega$ Objective}

This guidance note is intended to assist readers by elaborating on and explaining ADB's 2017 procurement policy and procurement regulations for borrowers (including grant recipients).

This note identifies additional information for the reader to consider when applying ADB's procurement policy and procurement regulations to their circumstances.

\section{F Living Document}

This guidance note is intended to be a living document and will be revised as required.

Be sure to check the ADB Business Center website for the latest version and updates, https://www.adb.org/business/main.

\section{? The Reader}

In many circumstances, readers are expected to use this guidance note in a manner unique to their needs. For consistency throughout the suite of guidance notes, the following assumption is made about the reader:

The reader is a professional involved in activities financed in whole or in part by an ADB loan or grant, or by ADB-administered funds.

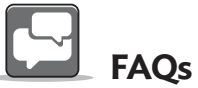

Frequently asked questions, clarifications, examples, additional information, links to training, and other useful resources will be made available on the ADB website.

Be sure to check the ADB Business Center website for more information, https://www.adb.org/business/main.

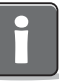

\section{Legal and Order of Priority}

This guidance note explains and elaborates on the provisions of the Procurement Regulations for ADB Borrowers: Goods, Works, Nonconsulting and Consulting Services (2017, as amended from time to time) applicable to executing (and implementing) agencies under sovereign (including subsovereign) projects financed in whole or in part by an investment loan from ADB (i.e., excluding ADB results- or policy-based loans), ADB-financed grant (excluding ADB-administered technical assistance and staff consultancies), or by ADB-administered funds.

In the event of any discrepancy between this guidance note and the procurement regulations, the latter will prevail. The financing agreement governs the legal relationships between the borrower and ADB. The rights and obligations between the borrower and the provider of goods, works, or services are governed by the specific procurement document issued by the borrower and by the contract signed between the borrower and the provider, and not by this guidance note. 


\section{ABBREVIATIONS}

$\begin{array}{lll}\text { ADB } & - & \text { Asian Development Bank } \\ \text { IFB } & - & \text { invitation for bids } \\ \text { RFP } & - & \text { request for proposals } \\ \text { VFM } & - & \text { value for money }\end{array}$


This guidance note provides information on the ADB process for reviewing a borrower's (or grant recipient's) procurement processes under projects financed in whole or in part by a loan or grant from ADB, or by ADB-administered funds. This review aims to ensure that the borrower's procurement processes comply with the terms of ADB's 2017 procurement regulations and those of the project's financing agreement, procurement plan, and relevant procurement documents.

This guidance note describes the two methods of ADB's procurement review: prior review and post review (sampling). The note discusses the method for determining the most appropriate type of review applicable to specific contracts under a project based on the project procurement risk rating and on contract values and complexity, and highlights other factors to consider in performing each type of review.

An effective procurement review may

\section{Increase Efficiency and Reduce Procurement Time}

- A risk-based approach in determining the type of procurement review improves efficiency by applying a fit-for-purpose review methodology.

- Appropriate use of post review (sampling) reduces procurement times by removing the need for ADB's prior review of each main step in the procurement process.

- Procurement reviews avert additional delays that may result from inadequate identification and handling of procurement risks and noncompliance.

\section{Reduce Risk}

- Procurement reviews identify risks and deficiencies in the borrower's procurement processes and recommend ways to mitigate them, thereby reducing risk of future noncompliance or project failure.

- Reduce the risk of bidding-related complaints.

- Improve compliance to audit requirements (both national and ADB).

\section{Deliver Value for Money}

- Procurement reviews decrease the risk of noncompliant practices that may adversely affect the project's achievement of value for money. 



\section{Introduction}

1.1 Procurement reviews are conducted by the Asian Development Bank $(A D B)$ to ensure that funds for projects financed in whole or in part by a loan or grant from $A D B$, or by $A D B$-administered funds, are used for purposes for which they were granted. Procurement reviews also work to ensure that procurement is conducted in accordance with the ADB Procurement Policy: Goods, Works, Nonconsulting and Consulting Services (2017, as amended from time to time) and the Procurement Regulations for ADB Borrowers: Goods, Works, Nonconsulting and Consulting Services (2017, as amended from time to time). Procurement reviews are conducted in one of two ways: (i) prior review, in which ADB reviews and approves key documents and decisions prior to them being implemented; or (ii) post review (sampling), in which ADB reviews documents, decisions, and procurement processes, on a sample basis, after contract signing.

1.2 Determining whether a procurement process is subject to prior or post review (sampling) is based on the project risk categorization, which is initially conducted at the project conceptualization stage and validated at the procurement planning stage of the ADB procurement cycle (Figure 1), considering planned procurement packages and specific project procurement risks. For more details, refer to the Guidance Note on Procurement Risk Framework and the Guidance Note on Strategic Procurement Planning.

1.3 The agreed review arrangement for each contract is indicated in the procurement plan. During procurement planning, if the validation of the project categorization results in a change in risk category, ADB may require the borrower (or grant recipient) to revise the prior or post review (sampling) requirements in the procurement plan. $\mathrm{ADB}$ and the borrower implement the agreed procurement review arrangements from the bidding stage (including advertising and prequalification, where used) through to the contract closure stage of the ADB procurement cycle (Figure 1).

1.4 This guidance note intends to assist users with the selection and application of the two types of procurement review: prior review and post review (sampling). The activities relating to procurement review commence at the planning stage with the aim of ensuring that procurement processes comply with the agreed principles and procedures and deliver value for money.

\footnotetext{
If the use of alternative procurement arrangements has been permitted under a particular project, a trust-and-verify procurement oversight approach will be applied, whereby ADB may not exercise prior or post review (sampling), but may rely on oversight mechanisms of the borrower or those agreed in the applicable financing or other agreements.
} 
Figure 1: The ADB Procurement Cycle

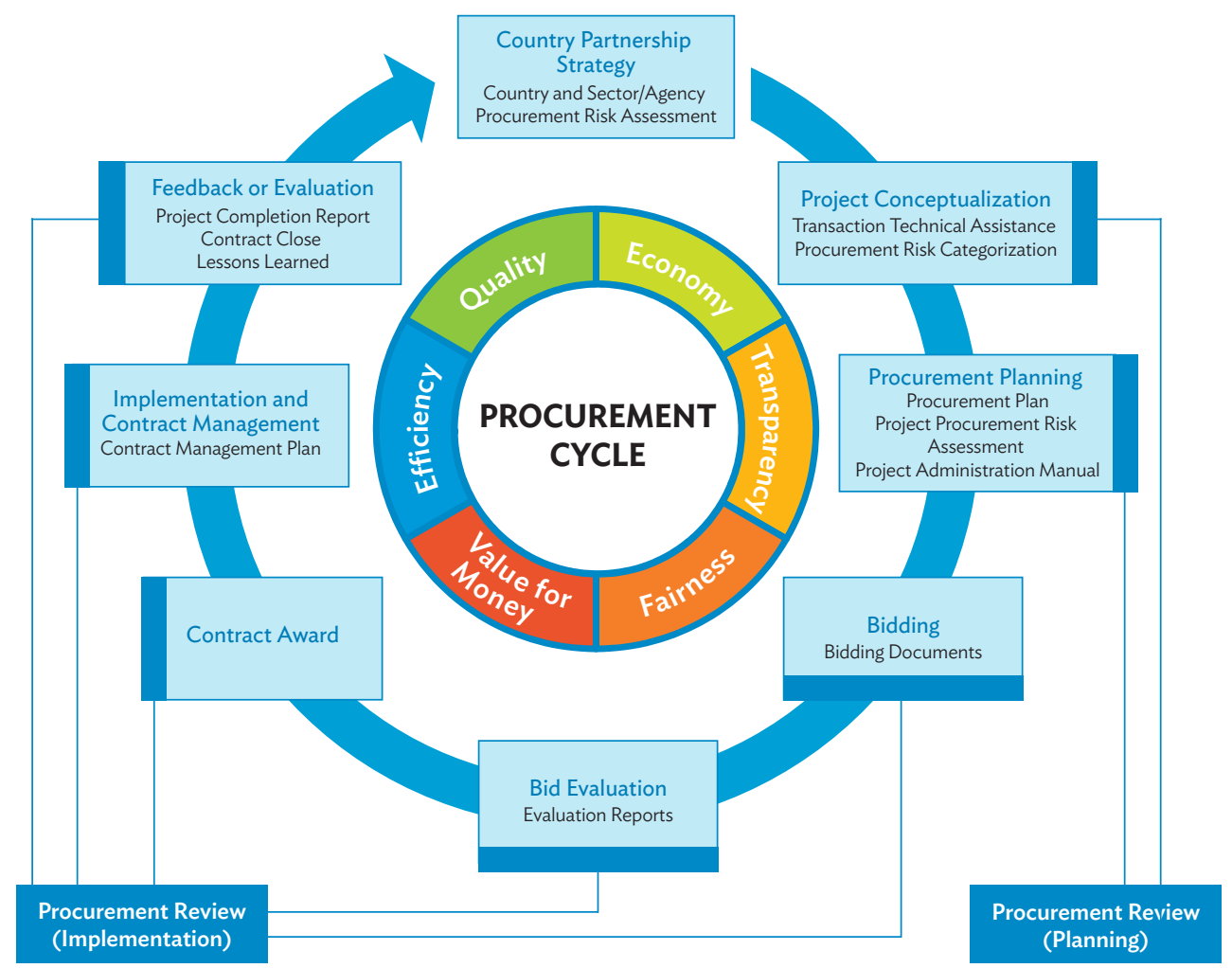

Source: Asian Development Bank. 


\section{Prior Review}

2.1 Prior review is conducted on contracts categorized as high risk during the project conceptualization stage, and as validated and specified in the project procurement plan (as endorsed by ADB) in conformity with the project's legal and financial agreements.

2.2 Prior review involves ADB reviewing and providing a "no-objection" prior to each step in the procurement process, to confirm that the borrower's proposed procurement actions comply with ADB's 2017 procurement policy and procurement regulations; and the project's financing agreement, procurement plan, and, where applicable, the provisions of the relevant procurement documents (collectively referred to as "the agreed procurement procedures"). Prior review includes reviews of the borrower's procurement procedures, documents, bid evaluations, award recommendations, and draft contracts. ${ }^{2}$ The borrower shall satisfactorily address ADB's comments, including making requested modifications to the reviewed documents.

2.3 Appendix 6 of the 2017 procurement regulations details the ADB prior review procedures applicable to open competitive bidding. The general requirements for prior review at key stages are as described in the following subsections.

\section{A. Prequalification (Shortlisting) Stage}

2.4 Prequalification (shortlisting) is generally used for consulting services and occasionally for procurement of works and plant. Where prequalification is used, ADB reviews the following documents:

(i) the text of the invitation to prequalify or request for expressions of interest, ${ }^{3}$

(ii) the prequalification documents or terms of reference,

(iii) the evaluation methodology or shortlisting criteria, and

(iv) a description of the advertising procedures to be followed.

2 For consulting selections by the borrower, the prior review process is generally compiled into "submissions." The number of submissions may vary from one to three, depending on the selection method, and will be agreed on in the procurement plan.

3 Prior review of this document is not usually requested for the borrower's consulting selections. 
2.5 The borrower must furnish the prequalification evaluation report and the list of prequalified or shortlisted applicants or consultants to ADB for its comments and no-objection before the applicants or consultants are notified of the borrower's decision.

\section{B. Prior to Issuing the Procurement Documents}

2.6 The documents for review include

(i) the draft invitation for bids ${ }^{4}$ and/or the letter of invitation to consultants; and

(ii) the draft bidding documents and/or the draft request for proposals (RFP), including the draft contract.

2.7 The first draft bidding documents and draft invitation for bids (IFB) 5 for each type of contract for goods, works, nonconsulting services, and consulting services, regardless of value, shall be prior reviewed before the publication of the IFB and issuance of bidding documents. For subsequent, low-risk contracts of similar type, the borrower may proceed with publishing the IFB and issuing the bidding documents to bidders, together with submitting the same to ADB for parallel review, so that any deficiencies in the bidding documents could be corrected through addenda before the bid submission date. However, such approach is applicable to borrowers that have demonstrated adequate capacity and that are willing to proceed with issuance of the bidding documents at their own risk.

\section{After Receipt of Bids or Proposals}

2.8 The documents for review include

(i) the bidding documents and/or the draft RFP as issued and (where relevant) as amended, including copies of questions received (if any) and answers given;

(ii) the technical evaluation report, where technical evaluation has taken place separately from financial evaluation, (most commonly used for selection of consulting services and the procurement of goods, works, and nonconsulting services under two-stage or two-envelope procedures);

(iii) the revised technical evaluation report and financial evaluation report together with the recommendation for contract award (for procurement contracts under two-stage procedures), before the expiry of any standstill provision, if applicable; and

(iv) the financial evaluation report together with the recommendation for contract award (or the overall ranking in the case of consulting), before the expiry of any standstill provision, if applicable.

4 This includes a request for quotation for goods, works, and nonconsulting services, if such procurement method is used.

5 This includes the draft RFP. 
2.9 No-objection. If ADB determines that the intended award would be inconsistent with the agreed procurement procedures, it will promptly inform the borrower of the reasons for such determination and will request the borrower to make necessary revisions. Otherwise, ADB will provide its no-objection to the recommendation for contract award or recommendation of the overall ranking (in the case of consulting).

\section{Decision on Award}

2.10 On receipt of the no-objection from $A D B$, the borrower will

(i) In the case of goods, works, and nonconsulting contracts, promptly issue notification of prequalification to successful applicants or notification of award to a successful bidder, or notification of intention to award (if a standstill period applies).

(ii) In the case of consulting services, proceed with contract negotiations with the first-ranked consultant and award the contract. ${ }^{6}$

\section{E. Following Award}

2.11 If the borrower receives complaints from applicants, bidders, or consultants following award, or at any stage of the procurement process, these will be addressed as further detailed in Appendix 7 of the 2017 procurement regulations and the Guidance Note on Bidding-Related Complaints.

2.12 After each contract is awarded, the borrower shall notify all applicants, bidders, or consultants about the results of the prequalification or bidding, and in case of contract award, shall furnish ADB a copy of the contract as executed.

\section{F. Other Approvals}

2.13 There may be cases where the procurement process does not result in contract award. In such situations, the borrower may recommend (i) cancellation and rebidding, or (ii) price negotiation with the lowest evaluated substantially responsive bidder. These recommendations are subject to ADB's prior review and issuance of no-objection. Recommendations for contract modifications are subject to ADB's prior review and issuance of no-objection if so specified in the relevant financing agreement. In addition, a contract management plan to be prepared before contract signing is also subject to ADB's prior review.

6 However, the executing agency should obtain the prior approval of ADB before agreeing with the consultant on any changes to the general or specific conditions of contract from those that ADB approved during its review of the draft procurement documents and draft contract. 


\section{Post Review (Sampling)}

3.1 If identified in the procurement plan, contracts not subject to ADB's prior review will be subject to post review (sampling) using a sampling methodology.

3.2 Procurement post review (sampling) may be conducted at each reimbursement cycle, when a series of withdrawal applications are received, or as part of project review missions by ADB or its consultants. Alternately, it may be organized as distinct post review missions on a regular basis (e.g., semiannually or annually) or on an ad hoc basis, whichever ADB finds to be most efficient. ADB's post review (sampling) is conducted to

(i) verify that procedures followed for procurement of specific contracts under the project comply with requirements of the agreed procurement procedures;

(ii) identify any deficiencies and noncompliance in the procurement processes;

(iii) propose mitigating measures to correct procurement deficiencies and deter future noncompliance;

(iv) identify and report any indications of possible integrity violations;

(v) identify good practices and lessons learned from undertaking the procurement;

(vi) rate the procurement process of sampled contracts in terms of compliance with the agreed procurement procedures, and their contribution to the overall procurement performance rating of the borrower; and

(vii) provide a basis for updating the project procurement risk assessment and the risk mitigation plan.

3.3 Post review (sampling) requirements typically are as follows:

(i) The borrower approves the award and ADB will only undertake post review on a sample of contracts awarded. For further details, refer to section IV of this guidance note. ${ }^{\text {? }}$

7 Note that, for the procurement of consulting services, ADB may also agree in the procurement plan to arrangements whereby it post reviews key documentation-typically the RFP and technical evaluation report-while the procurement process is still ongoing. In this case, the executing agency sends the documents to ADB immediately after their issuance or completion and ADB may propose amendments in a timely manner. Details on this review option, if used, would be agreed between ADB and the borrower in the procurement plan, and this option is not discussed further in this guidance note. 
(ii) The borrower must retain all documentation with respect to each contract where post review (sampling) was adopted during project implementation and for at least 1 year after the project closing date. This documentation generally includes advertisements or procurement notices (such as the request for expressions of interest or invitation for prequalification, and letter of invitation to consultants or invitation for bids); prequalification documents; prequalification or shortlisting evaluation reports; bidding documents or RFP; bids or proposals, including any amendments and clarifications; evaluation reports (including the analysis of the respective proposals and recommendations for award); the original signed contract; and documents concerning any bidding-related complaints.

(iii) Master copies of electronic documents, if applicable, must be retained in print form, suitably authenticated by the issuing agency by signature, stamp, or other features acceptable to ADB. Alternatively, audit trails can be made available in case an electronic procurement system was used and documents are in electronic format.

(iv) The borrower shall furnish the required documentation to ADB personnel or its consultants assigned to conduct post review (sampling) during the project review or post review mission(s). If post review is not completed within 6 months after receipt of documents, the borrower may assume that ADB has no objection to the award of contract.

(v) If $A D B$ determines that the goods, works, or services were not procured in accordance with the agreed procedures as reflected in the procurement plan, or an action by a borrower amounted to noncompliance, it may take appropriate action consistent with paras. 1.29 and 1.30 of the 2017 procurement regulations and the Guidance Note on Noncompliance in Procurement.

(vi) Since noncompliance may mean refunding if amounts have been disbursed, post review (sampling) should be conducted in a timely manner so that corrective measures may be taken. 


\section{Contract Review and Sampling Methodology}

\section{A. Planning for Post Review (Sampling)}

4.1 Sample contracts may be reviewed at each reimbursement cycle or series of withdrawal applications, on a regular basis, or when each review or supervision mission is fielded. Sample contracts are determined based on the list of post review contracts awarded furnished to ADB by the borrower before each project supervision or post review mission. When requesting for such lists, ADB will ensure that all post review contracts are included by carefully monitoring the coverage of each list. The list template is attached in the Appendix, section $B$, which will form part of the post review (sampling) report.

4.2 It is recommended that the borrower initiates post review (sampling) and informs ADB immediately after $25 \%-50 \%$ of the value of contracts under post review (sampling) stated in the procurement plan were signed. For efficiency, post review (sampling) may be scheduled and conducted for more than one project implemented by the borrower or for multiple projects located in the same region.

4.3 Under post review (sampling), the borrower approves the award and signs the contracts, while ADB will post review only a sample of contracts awarded and signed. The sample size should endeavor to capture contracts representing (i) about $30 \%-50 \%$ of total project value and (ii) about $20 \%$ of the total number of contracts identified for post review (sampling) (Figure 2). ADB should ensure that, to the extent possible, all types of contracts are included in the sample.

4.4 The sample size is indicative only and will depend on the nature of the project and extent of risks. For example, in the case of projects with many small contracts, $20 \%$ coverage may be unrealistic. On the other hand, for projects where the risk classification is "substantial" or "high" (refer to the Guidance Note on Strategic Procurement Planning), all contracts may undergo prior review. The scope of the sample will be determined in the project administration manual and the procurement plan.

\section{B. Sampling Methodology}

4.5 The sampling methodology is based on the value, nature, and distribution of post review (sampling) contracts and the project's procurement and integrity risks, including the capacity of the borrower and its executing and implementing 
Figure 2: Indicative Sample Size for Post Review
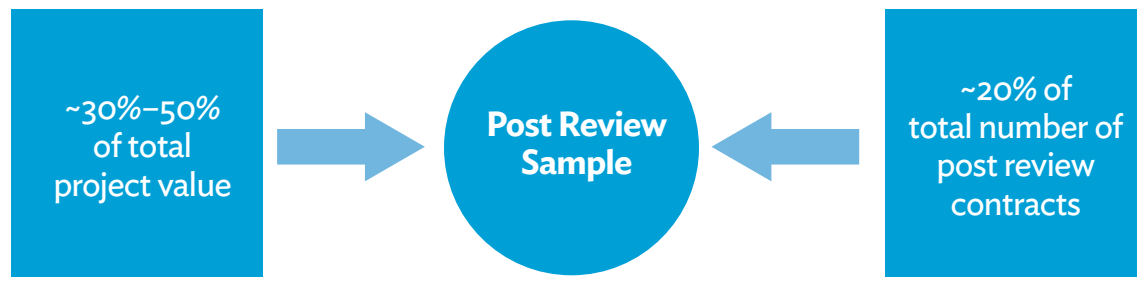

Source: Asian Development Bank.

agencies (see Box). The sampling methodology should cover contracts amounting to a representative range of the total number of transactions covered by the project procurement plan in terms of value and number, but including in the sample the review of all types of contracts identified in the plan. Contracts chosen for post review (sampling) are based essentially on a process of stratified random sampling.

\section{Box}

Variables to Consider When

Creating Groups of Similar Contracts for Post Review (Sampling)

- Value of contracts

- Nature or type of contracts

- Distribution of contracts

- Procurement risks

- Integrity risks

Source: Asian Development Bank.

4.6 The key steps are as follows:

(i) review the list of signed contracts subject to post review (sampling) under the project furnished by the borrower and check the completeness of the list against available data, e.g., the procurement plan, disbursement reports or periodic procurement reports, and any available payment records;

(ii) create an initial sample of selected contracts grouped (stratified) by value, e.g., contracts below $\$ 1$ million, between $\$ 1$ million and $\$ 5$ million, between $\$ 5$ million and $\$ 10$ million, etc.;

(iii) consider whether any of the contracts listed have raised concern and ensure that these are subject to review as part of the sample. This could apply to contracts

(a) against which a complaint has been submitted;

(b) for which rebidding or cancellation of the procurement took place;

(c) with price modifications of $15 \%$ or more of the original contract price;

(d) not listed in the procurement plan;

(e) awarded without competition (direct contracting);

(f) awarded by the borrower for which deficiencies were found in previous post reviews; and 
(g) where there have been abnormally long delays between bid submission and evaluation, between evaluation and contract award, or between contract award and contract execution.

If the number of contracts meeting the above characteristics exceeds the identified sample size, the sample size may be increased (if resources allow) or a smaller representative sample may be drawn from these contracts, depending on the reasons for this elevated level of risk.

\section{Review Methodology}

4.7 After the sample has been determined, ADB should agree with the borrower on the post review (sampling) schedules. The contracts chosen for post review (sampling) will be informed when the mission arrives and the borrower shall make all relevant documents available upon the mission's request. A post review (sampling) report (Appendix, section A) shall be prepared by ADB for each post review (sampling) exercise.

4.8 Before starting the review, the results of any previous post reviews under the project should be considered, to assess the issues raised in the last review(s) and how they have been addressed, as well as any outstanding mitigation actions and other issues from implementation support and monitoring. This will provide an indication of the areas requiring special attention. When previous corrective actions remain unfinished beyond their due date, the report shall discuss whether the actions are still relevant and record any reasons why the actions were not implemented. When the measures were implemented, ADB will assess whether the borrower effectively mitigated the identified risks. Progress with pending actions are discussed with the borrower as part of the review.

4.9 Whenever significant noncompliance is observed, ADB will gather (and make copies of) evidence of records that reflect the noncompliance-for example, extracts of evaluation reports, solicitation documents, or payment records, and collect copies of such records. The borrower retains the original records.

\section{Overall Approach}

4.10 Post review (sampling) covers compliance of the procurement process with the agreed procurement procedures. ADB shall exercise professional judgment in assessing the adequacy of the procurement and how it was conducted, with support of the guiding questions described in the post review (sampling) report template in the Appendix. For example, it should not be simply reported that bidders were given less time than agreed to prepare and submit bids. Instead, assessment should be made on whether the time was reasonable or adequate to enable bidders to prepare and submit responsive bids under the circumstances of the contract, as well as the reasons for this deviation. 
4.11 In conducting the review, an assessment shall be made whether the borrower continues to comply with the agreed procurement procedures and if the procedures are still adequate for timely and effective implementation of procurement. In cases of potential noncompliance, further assessments, including discussions with project staff, shall be conducted to establish any underlying causes or system failures. This may require reviewing other reports such as internal audit reports and project procurement-related review reports. For example, when several instances of noncompliance are observed, it could be because of lack of capacity of the borrower's staff to undertake procurement actions properly or due to bypassing the borrower's internal procurement approval procedures, which would be considered as a system failure. In both cases, corrective actions shall be proposed and their future implementation monitored.

\section{E. Integrity Violations}

4.12 ADB staff will check the list of contracts against ADB's list of suspended and debarred firms and individuals, including any entities debarred or suspended under the multilateral development banks' Agreement for Mutual Enforcement of Debarment Decisions (2006). This includes contracts with a firm that may have been signed after the date of the firm's debarment or suspension. The list of contracts shall be also reviewed to identify any unusual patterns indicating risky activities - for example, repetitive contracts; orders of the same items from the same firms (except under framework agreements); multiple contracts procured through direct contracting; or inconsistencies in different bids submitted by the same bidder, affecting its responsiveness for different contracts. Contracts exhibiting such patterns may be added to the sample of contracts to be reviewed.

4.13 When any suspected cases of integrity violations are identified through the post review (sampling) process, the relevant documentation will be collected and the suspected violations will be recorded in the post review (sampling) report, which shall be copied to ADB's Office of Anticorruption and Integrity.

\section{F. Post Review (Sampling) Rating}

4.14 Each borrower is rated on its management of the procurement process, concerning compliance with the agreed procurement procedures, which shall be evaluated as "satisfactory," "partly satisfactory," or "unsatisfactory." Based on the status of the assessment, the overall risk rating will be classified as extreme, high, medium, or low. In reaching conclusions on these ratings, the following issues will be considered:

(i) procurement planning: assessment of quality of, and adherence to, the procurement plan, including changes or updates, if applicable;

(ii) publications: assessment of quality of, and adherence to, advertising and contract award publication requirements for applicable contracts; 
(iii) bidding: assessment of quality of, and adherence to, requirements of bidding documents, including RFPs, short lists, terms of reference, and other applicable documents;

(iv) evaluation: assessment of quality of, and adherence to, bid evaluation requirements or criteria, including draft contracts, technical and financial evaluation reports, and amendments to bidding documents, if applicable; and

(v) awards: assessment of quality of, and adherence to, contract award requirements.

4.15 Based on these findings, ADB assigns an overall risk rating for the review in accordance with the descriptions in the Table. Findings on noncompliance form part of the key recommendations for corrective action.

Table: Risk Rating Descriptions for ADB's Post Review (Sampling) Report

\begin{tabular}{ll}
\hline Extreme risk & \multicolumn{1}{c}{ Overall Risk Rating } \\
& $\begin{array}{l}\text { Significant shortcomings in borrower processes and practices in } \\
\text { procurement, which may jeopardize the timely or efficient achievement of } \\
\text { one or more major outputs, or compromise the integrity of the processes, } \\
\text { the resolution of which is uncertain or unlikely. }\end{array}$ \\
\hline High risk & $\begin{array}{l}\text { Some shortcomings in borrower processes and practices in procurement, } \\
\text { which may jeopardize the timely or efficient achievement of one or more } \\
\text { major outputs, or compromise the integrity of the processes, the resolution } \\
\text { of which is uncertain. }\end{array}$ \\
\hline Medium risk & $\begin{array}{l}\text { Borrower procurement processes and practices are of generally } \\
\text { good quality, reliability, timeliness, and transparency, with moderate } \\
\text { shortcomings requiring only minor corrective actions or, when there are } \\
\text { more significant shortcomings, their timely resolution is likely. }\end{array}$ \\
\hline $\begin{array}{l}\text { Borrower procurement processes and practices are of high quality, } \\
\text { reliability, timeliness, and transparency, and require little or no corrective } \\
\text { action by ADB. }\end{array}$
\end{tabular}

Source: Asian Development Bank.

4.16 Before completing the review, the findings shall be discussed with the borrower. This provides the borrower's staff the opportunity to clarify any issues and helps gain the borrower's acceptance of the conclusions and recommendations in the report. While clarifications and discussions may be carried out with the borrower's procurement staff, they should include the project manager or coordinator to give him or her an overview of the borrower's procurement performance. When mitigating or strengthening actions are necessary, the reviewer discusses these potential actions and their target dates to improve the chances of effective implementation. When recommendations from previous reviews are still outstanding, the reviewer discusses the reasons, reflects them in the report, and considers them in developing any new actions. 


\section{Appendix: Templates for Post Review (Sampling)}

\section{A. Procurement Post Review (Sampling) Report Template}

[To be prepared by Asian Development Bank (ADB) staff or consultants upon completion of a post review (sampling) mission.]

\begin{tabular}{|c|c|}
\hline \multicolumn{2}{|l|}{ Project Name: } \\
\hline Project Number: & Approval Number: \\
\hline Country: & Executing Agency: \\
\hline Project Procurement Risk Categories: & \multirow[t]{2}{*}{ Implementing Agency: } \\
\hline Procurement Risk: & \\
\hline Post Review (Sampling) Conducted by: & Project Closing Date: \\
\hline Date of Last Post Review (Sampling): & Date of this Post Review (Sampling): \\
\hline $\begin{array}{l}\text { No. of Contracts Awarded } \\
\text { since last Review: }\end{array}$ & No. of Contracts Reviewed: ${ }^{a}$ \\
\hline
\end{tabular}

a Refer to Appendix 1, section B.

\section{Executive Summary}

[Brief description of post review (sampling) objective, key findings and issues, and recommendations.]

2. Discussion on the Selection of the Contract Samples to be Reviewed and List of Contracts Reviewed

[Brief description of the selection of

- the contract sample (whether by risk, random selection, or both); and

- summary list of the contracts reviewed (including details such as type of procurement, procurement method, contract number, contract date, short contract description, name of contracting agency, name of contractor/supplier/consultant, contract amount).

The borrower should prepare this following the template in Appendix 1, section B.]

\section{Findings of the Review}

[a. Description of progress on the recommendations and actions submitted in the last post review (sampling) (if applicable).

b. Brief description of findings of the current review, covering procurement processes, including procurement planning, publications, bidding, evaluation, and awards. 
This should be based on the sample worksheets in Appendix 1, sections $C$ to $E$, as relevant.

c. Brief description of any findings that suggest potential integrity violations related to the procurement processes, or any other related issues at contract, project, sector, or country level.]

\section{Post Review (Sampling) Rating and Recommendations}

[Overall rating ("extreme," "high," "medium," or "low" risk, per the definitions below) of the borrower's performance on managing the procurement process during the review period, and recommendations to address any assessed risks and issues of noncompliance.

Definitions of post review (sampling) risk ratings applied to managing the procurement process:

Extreme risk: Significant shortcomings in borrower processes and practices in procurement, which may jeopardize the timely or efficient achievement of one or more major outputs, or compromise the integrity of the processes, the resolution of which is uncertain or unlikely.

High risk: Some shortcomings in borrower processes and practices in procurement, which may jeopardize the timely or efficient achievement of one or more major outputs, or compromise the integrity of the processes, the resolution of which is uncertain.

Medium risk: Borrower procurement processes and practices are of generally good quality, reliability, timeliness, and transparency, with moderate shortcomings requiring only minor corrective actions or, when there are more significant shortcomings, their timely resolution is likely.

Low risk: Borrower procurement processes and practices are of high quality, reliability, timeliness, and transparency, and require little or no corrective action by ADB.]

\section{Compliance Status of Procurement Processes}

[i.e., compliance with the financing agreement, procurement regulations, and other agreed provisions]

\section{Satisfactory $\square$ Partly Satisfactory $\square$ Unsatisfactory}

[Indicators to consider:

- Procurement Planning: Assessment of quality of, and adherence to, the procurement plan, including changes or updates if applicable

- Publications: Assessment of quality of, and adherence to, advertising and contract award publication requirements for applicable contracts

- Bidding: Assessment of quality of, and adherence to, requirements for bidding documents, including requests for proposals or invitations to bid, short lists, terms of reference, and other applicable documents

- Evaluation: Assessment of quality of, and adherence to, bid evaluation requirements or criteria, including draft contracts, technical and financial evaluation reports, and bid amendments, if applicable

- Awards: Assessment of quality of, and adherence to, contract award requirements]

Recommendations:
[List mitigating measures recommended to address the identified issues regarding the borrower's management of the procurement process.] 


\section{B. List of Post Review (Sampling) Contracts}

[To be prepared by the borrower in advance. If the project has more than one executing agency and/or implementing agency, each will prepare a list that will be consolidated by a coordinating party.]

Awarded from [dd/mm/yyyy] to [dd/mm/yyyy]

By: [name of executing or implementing agency]

\begin{tabular}{|l|l|l|l|l|l|l|l|}
\hline $\begin{array}{l}\text { Contract } \\
\text { Number and } \\
\text { Description }\end{array}$ & $\begin{array}{c}\text { Procurement } \\
\text { or Selection } \\
\text { Method }\end{array}$ & $\begin{array}{c}\text { Bidding } \\
\text { Procedure }\end{array}$ & $\begin{array}{c}\text { Estimated } \\
\text { Cost }\end{array}$ & $\begin{array}{c}\text { Contract } \\
\text { Award } \\
\text { Amount }\end{array}$ & $\begin{array}{c}\text { Date of } \\
\text { Award }\end{array}$ & $\begin{array}{c}\text { Winner } \\
\text { and } \\
\text { Address }\end{array}$ & $\begin{array}{c}\text { Implementation } \\
\text { Status }\end{array}$ \\
\hline Works & & & & & & \\
\hline 1 & & & & & & \\
\hline 2 & & & & & & \\
\hline Goods & & & & & & \\
\hline 1 & & & & & & \\
\hline 2 & & & & & & \\
\hline Nonconsulting & & & & & & \\
\hline 1 & & & & & & & \\
\hline 2 & & & & & & & \\
\hline Services & & & & & & & \\
\hline Sonsulting & & & & & & & \\
\hline 1 & & & & & & & \\
\hline 2 & & & & & & & \\
\hline
\end{tabular}

${ }^{a}$ In case of works, goods, and nonconsulting services.

${ }^{b}$ From the approved procurement plan.

c "In progress" or "completed." 


\section{Post Review (Sampling) Worksheet for Request for Quotation Procedures}

[To be prepared by ADB only for contracts with major compliance issues.]

\begin{tabular}{|l|l|}
\hline Date of Review: & Name of Reviewer: \\
\hline Contract Number and Date: & Contract Amount (\$): \\
\hline Contractor's Name and Address: & \\
\hline
\end{tabular}

\begin{tabular}{|l|l|}
\hline Aspects & Comments and Findings \\
\hline Procurement documentation (filing) & \\
\hline Reference in procurement plan & \\
\hline $\begin{array}{l}\text { Request for quotation issued to firms and the } \\
\text { number of firms to whom sent }\end{array}$ & \\
\hline Time allowed for submission of quotations & \\
\hline $\begin{array}{l}\text { Verification (not evaluation) of existence of } \\
\text { the quotations and names of suppliers who } \\
\text { gave quotations }\end{array}$ & \\
\hline $\begin{array}{l}\text { Quotation evaluation report and date, and } \\
\text { comments, if any }\end{array}$ & \\
\hline Signed contract or purchase order document & \\
\hline Complaints or related matters & \\
\hline Indication of possible integrity violations & \\
\hline Other matters & \\
\hline
\end{tabular}




\section{Post Review (Sampling) Worksheet for Other Bidding Procedures}

[To be prepared by ADB only for contracts with major compliance issues.]

\begin{tabular}{|l|l|}
\hline Date of Review: & \multicolumn{2}{|c|}{ Name of Reviewer: } \\
\hline Contract Number and Date: & Contract Amount (\$): \\
\hline Contractor's Name and Address: & \\
\hline
\end{tabular}

Procurement Method:
$\square$ OCB $\square$ LCB
$\square$ Direct Contracting $\square$ Others, specify:

Type:

$\square$ Goods $\square$ Works $\square$ Nonconsulting Services

\begin{tabular}{|l|l|}
\hline Aspects & Comments and Findings \\
\hline Procurement documentation (filing) & \\
\hline Reference in procurement plan & \\
\hline Advertising & \\
\hline Pre- or post qualification & \\
\hline Bidding document & \\
\hline Time allowed for submission of bids & \\
\hline Bid opening and minutes of bid opening & \\
\hline Bid security records & \\
\hline Bid evaluation reports, verify existence of bids, names of bidders & \\
\hline Debriefing & \\
\hline Publication of contract award & \\
\hline Contract document & \\
\hline Complaints or related matters & \\
\hline Indication of possible integrity violations & \\
\hline Other matters & \\
\hline Justification for direct contracting (if applicable) & \\
\hline
\end{tabular}

$\mathrm{LCB}=$ limited competitive bidding, $\mathrm{OCB}=$ open competitive bidding. 


\section{E. Post Review (Sampling) Worksheet for Consultant Contracts}

[To be prepared by ADB only for contracts with major compliance issues.]

Date of Review:

Contract Number and Date:

Contractor's Name and Address:

\section{Name of Reviewer:}

Contract Amount (\$):
Evaluation
$\square$ QCBS
$\square$ QBS
FBS
LCS
Method:
$\square \operatorname{CQS}$
SSS
Others, specify:

Category: $\square$ Firm $\square$ Individual

\begin{tabular}{|l|l|}
\hline Aspects & Comments and Findings \\
\hline Procurement documentation (filing) & \\
\hline Reference in procurement plan & \\
\hline Advertising & \\
\hline Request for proposals & \\
\hline Short list: verify number, names, etc. & \\
\hline Time allowed for submission of proposals & \\
\hline Evaluation criteria & \\
\hline Technical evaluation & \\
\hline Evaluation report, and comments, if any (verify existence & \\
\hline of proposals) & \\
\hline Financial bid opening & \\
\hline Combined quality and cost evaluation & \\
\hline Publication of contract award & \\
\hline Signed contract document & \\
\hline Complaints or related matters & \\
\hline Indication of possible integrity violations & \\
\hline Other matters & \\
\hline Justification for single-source selection (if applicable) & \\
\hline
\end{tabular}

$\mathrm{CQS}=$ consultants' qualifications selection, $\mathrm{FBS}=$ fixed budget selection, $\mathrm{LCS}=$ least - cost selection, $\mathrm{QBS}$ = quality-based selection, $\mathrm{QCBS}$ = quality- and cost-based selection, SSS $=$ single-source selection. 


\section{Procurement Review \\ Guidance Note on Procurement}

This guidance note provides information on the two methods that ADB uses to review a borrower's procurement processes: prior review and post review (sampling). This applies to projects financed in whole or in part by a loan or grant from ADB, or by ADB-administered funds. The review aims to ensure that the borrower's procurement processes comply with the agreed procurement procedures. This guidance note discusses the method for determining the most appropriate type of review applicable to specific contracts based on the project procurement risk rating and on contract values and complexity, and highlights other factors to consider in performing each type of review.

\section{About the Asian Development Bank}

ADB's vision is an Asia and Pacific region free of poverty. Its mission is to help its developing member countries reduce poverty and improve the quality of life of their people. Despite the region's many successes, it remains home to a large share of the world's poor. ADB is committed to reducing poverty through inclusive economic growth, environmentally sustainable growth, and regional integration.

Based in Manila, ADB is owned by 67 members, including 48 from the region. Its main instruments for helping its developing member countries are policy dialogue, loans, equity investments, guarantees, grants, and technical assistance.

\section{$\mathrm{ADB}$}

